\section{IDŐSKORI ÖNGONDOSKODÁS ELTÉRŐ VÁRHATÓ ÉLETTARTAM ESETÉN}

Ágoston Kolos Csaba (PhD, Budapesti Corvinus Egyetem, egyetemi docens) kolos.agoston@uni-corvinus.hu

\section{ÖSSZEFOGLALÓ}

Nyugdíjba vonuláskor a befizetett járulék egy meghatározott képlet szerint nyugdíjkifizetést eredményez. A nyugdíjképletek jellemzően a várhatóan hosszabb ideig élőknek kedveznek a későbbi nyugdíjba vonulás kelleténél nagyobb honorálása miatt. Ebben a munkában egy olyan időskori öngondoskodási rendszert mutatok be, ahol a nyugdíjas rugalmasan alakíthatja jövedelmét az (élet)járadékszolgáltatás és az egyéni bankszámla között. Állami beavatkozással az antiszelekcióból eredő jóléti veszteség csökkenthető, de nem szüntethető meg.

\section{SUMMARY}

After retirement the pension contributions are transformed into allowances following a specific pension formula. Pension formulas favour people with longer life expectancy because of the overvaluation of late retirement. In this paper I show an elderly self-care system where the pensioner can flexibly variate his/her income between allowances and private bank account. Public intervention allows for reducing but not completely eliminating welfare losses due to anti-selection.

Kulcsszavak: Nyugdíjrendszerek, antiszelekció, döntések bizonytalanság esetén, életpálya hasznosság

Key words: pension schemes, anti selection, choice under uncertainty, life-cycle hypothesis

\section{JEL: H55, D63, D91, D81}

DOI: $10.18530 /$ BK.2016.1.44

http://dx.doi.org/1018530/BK.2016.1.44

\section{Bevezetés}

Nyugdíjrendszerek tervezésekor a néphalandósági tábla alapján kalkulálják a nyugdíjjáradék mértékét. Várható élettartam szerint homogén társadalomban ez teljesen kielégítő megoldás, azonban az empirikus vizsgálatok azt mutatják, hogy a társadalom élettartam szerint nem homogén. Talán a legismertebb példa a férfi és női élettartamok közötti különbségek, de szintén közismert, hogy az élettartam különbözik iskolai végzettség szerint, sőt, még Budapest egyes kerületei között is.

A várható élettartam szerinti különbségek a nyugdíjrendszerben még nem feltétlenül okoznának problémát, de a tapasztalat szerint a dolgozók tisztában vannak azzal, hogy az élettartamuk (várhatóan) kisebb vagy nagyobb, mint az átlag. Krémer (2013) éleslátóan mutatta be, hogy a kisnyugdíjasok gyorsabb kihalása miatt az induláskor nagyon aszimmetrikus nyugdíjeloszlás hogyan válik szimmetrikussá az antiszelekció hatására. Szintén közismert tény, hogy a (magánbiztosítói) járadékosok halandósága jelentősen jobb, mint az országos átlag. A közgazdaságtan a leírt jelenséget, amelynek kiterjedt irodalma van, antiszelekciónak nevezi. Piaci kudarchoz vezet az, ha nem vesszük figyelembe, hogy a társadalomban különböző típusok vannak, és egyszerűen az összsokaságra vonatkozó adatok alapján árazzuk be a szolgáltatást. Kötelező nyugdíjrendszer esetében a részvétel kötelező, így nem beszélhetünk piaci kudarcról rögzített nyugdíjkorhatár esetén. Ha a nyugdíjba menetel időpontját a dolgozók (bizonyos határok között) szabadon megválaszthatják, az antiszelekció kérdése ismét felmerül. Az összsokasági arányok (pl.: KSH néphalandósági tábla) alapján számoló nyugdíjképlet a társadalom csoportjai közötti újraelosztást okoz; általában a várhatóan hosszabb élettartamúak tudnak profitálni az effajta nyugdíjképletből (ezt a magyar szakirodalomban perverz újraelosztásnak nevezik).

Simonovits András ${ }^{1}$ és szerzőtársai több cikket is publikáltak a rugalmas nyugdíjrendszer témakörében (Eső és Simonovits, 2003; Eső, Simonovits és Tóth, 2011). Modelljeik közös alapfeltevése, hogy a nyugdíjrendszer résztvevőinek várható élettartama eltér, és ezzel a szereplők is tisztában vannak. Az állam viszont nem képes ezeket a típusokat megkülönböztetni, vagy ha esetleg képes is lenne erre, nem teheti. Hogyan tudja az állam a járadékszintek megszabásával arra ösztönözni a szereplöket, hogy a várható élettartamukhoz igazodó járadékszintet (nyugdíjat) válasszanak? Lehet-e a csoportok közötti keresztfinanszírozással a társadalom csoportjainak helyzetén javítani?

A modell egyik korlátja, hogy az emberi élettartamot biztosnak (determinisztikusnak) tekintette. Banyár József (Banyár, 2011) ezt a momentumot vitatta, és azt állította hogy a járadékfüggvények megfelelő megválasztásával kezelhető a felvetett probléma. Banyár József cikkében nem számolt a fogyasztói döntésekkel (egészen pontosan nem 
hasznosságfüggvényekkel operál, a Pareto-optimalitást ${ }^{2}$ nem vizsgálja). Simonovits András válaszában (Simonovits, 2012) részben elismerte a kritika jogosságát, de egy újabb modell segítségével megmutatta, hogy a felvetett problémák fennállnak akkor is, ha nem biztos a várható élettartam. Sajnos ebben a modellben kényszerűségből Simonovits András is lemondott a fogyasztói döntések elemzéséről, csak a nyugdíjrendszer egyéni és aggregált egyenlegére koncentrál.

\section{Kiindulunk egy piaci rendszerből, és megvizsgáljuk, \\ hogy keresztfinanszírozással (állami beavatkozással) javítható-e a szereplők helyzete.}

Jelen munkával ehhez a vitához szeretnék hozzájárulni. A cikkben kifejezetten a vita során mellőzött kérdést vizsgálom. Mivel a rugalmas nyugdíjrendszer eredeti modellje is kellően bonyolult, ebbe beépítve a bizonytalan várható élettartamot, és az ehhez kapcsolódó fogyasztói döntések vizsgálatát, már átláthatatlanul bonyolulttá válna a modell - ezt Simonovits András is elismeri. Ezért egy másik kiindulópontból vizsgálom a kérdést. A modell így nem tekinthető sem a rugalmas nyugdíjrendszer kiterjesztésének, sem egy piaci helyzet modellezésének, e helyett arra szolgál, hogy a rugalmas nyugdíjrendszer modelljében a szereplők érdekei és a feltételek korlátai jobban körüljárhatóvá váljanak. A probléma elemzésekor hasonló utat járunk be, mint Eckstein-Eichenbaum-Peled (1985): kiindulunk egy piaci rendszerből, és megvizsgáljuk, hogy keresztfinanszírozással (állami beavatkozással) javítható-e a szereplők helyzete.

\section{A modell}

Modellünkben kiindulásként piaci viszonyokat tételezünk fel. Többféle dolgozó szeretné átváltani megtakarítását járadék ká, akiknek az élettartama bizonytalan, ezért a járadék várható értéke különbözik. A döntéshozók ismerik saját várható élettartamukat, de a járadékszolgáltató a döntéshozókat nem tudja megkülönböztetni. A (minimális nyugdíjkorhatár elérésekor felhalmozott) megtakarítások nagysága legyen $S$, ami az egyszerüség kedvéért egyforma minden típusra. Jelölje $p_{t}^{i}$ azt a valószínűséget, hogy az $i$ típus $t$ év elteltével életben van.

A piacon különböző járadékok érhetők el. Mivel valamilyen szinten a nyugdíjrendszert szeretnénk modellezni, ezért konstans tagú járadékot vizsgálunk (engedélyezünk). A járadékok lehetnek azonnal induló (élet)járadékok és halasztott (élet)járadékok. A járadékszolgáltatók nem tudnak különbséget tenni a járadékosok között. Jelölje $\ddot{a}_{t}$ azt, hogy a t évvel halasztott járadék esetén 1 egységnyi járadéknak mennyi a (nettó) díja (62 éves korban). Az $i$ típusú döntéshozó összegű járadékot vásárol a tévvel halasztott járadékból. A modellben minden döntéshozó maximum egy járadékot vásárolhat.

A döntéshozóknak nem kell az összes tőkéjükből járadékot venniük, lehetőségük van ún. ütemezett bankkivétként (angolul dissaving) is elfogyasztani a tőkéjüket. Ütemezett bankkivét esetén elhalálozáskor a bankszámlán lévő pénz a döntéshozó számára elvész (az örökülhagyási motivációt figyelmen kívül hagyjuk). Az $i$ típus esetén jelölje $p_{t}^{i}$ a tév elteltével kivett pénzt. Az ütemezett bankkivét lehetősége nem szerepel a rugalmas nyugdíjrendszer modelljében, így ez új elemnek tekinthető. Egy piaci modellben viszont nem kerülhető meg, mert nincs olyan kényszer, amely a felhalmozott tőke járadékra váltását okozná. Megjegyezzük egyébként (anélkül, hogy a rugalmas nyugdíjrendszer hibájául rónánk fel), hogy a valós helyzettől sem idegen, hogy nem a nyugdíj az öregkori gondoskodás egyetlen eszköze, hanem egyéb jövedelemkiegészítési lehetőségek vannak; manapság éppen ilyen megtakarításokra ösztönzi az állam a polgárait. Szintén érdemes megjegyezni (bár a szabályozás még képlékeny), hogy jelen formájukban az önkéntes nyugdijpénztárak szolgáltatásai - lényegüket tekintve - ilyen ütemezett bankkivétnek feleltethetők meg.

A döntéshozó különbözö tervek közül szeretné kiválasztani azt, amelyik ízlésének a legjobban megfelel. Feltesszük, hogy ezeket a terveket rangsorolni tudja, ezt egy életpálya-hasznosságfüggvény reprezentálja:

$$
u^{i}\left(t, a_{t}^{i}, b_{1}^{i}, b_{2}^{i}, b_{3}^{i} \ldots\right)=\sum_{\tau=0}^{t-1} p_{\tau}^{i} \frac{\left(b_{\tau}^{i}\right)^{1-\beta}}{1-\beta}+\sum_{\tau=t}^{\pi} p_{\tau}^{i} \frac{\left(b_{\tau}^{i}+a_{t}^{i}\right)^{1-\beta}}{1-\beta}
$$

ahol $\pi$ az emberi élet végső határa, $\beta$ pedig a döntéshozó kockázatelutasítását kifejező paraméter.

Látjuk, hogy ha a döntéshozó halasztott életjáradék vásárlása mellett dönt, akkor az időszak elején a felhalmozott tőkéből ütemezett bankkivétek segítségével tud gondoskodni magáról.

A választott (1) hasznosságfüggvény elfogadottnak tekintett a vonatkozó szakirodalomban (lásd pl.: Fischer, 1973, Kotlikoff és Spivak, 1981, valamint Mitchell et al., 1999 ).

A döntéshozó csak olyan tervet választhat, amely számára megvalósítható, azaz teljesülnie kell az ún. költségvetési korlátnak:

$$
S=\ddot{a}_{t} a_{t}^{i}+\sum_{\tau=0}^{\omega} p_{\tau}^{i} b_{\tau}^{i}
$$

Természetesen a járadék összegének és a bankkivéteknek nemnegatívnak kell lenniük.

Az igazi kérdés, hogy a járadékszolgáltató milyen árakat határoz meg. A járadékszolgáltató figyelembe veszi a típusok egyéni optimalizációját, és olyan árakat kell meghatároznia, hogy a típusok racionális választása ne okozzon veszteséget a számára, ezt szoktuk ösztönzési korlátnak nevezni. Az ösztönzési korlát explicit felírását az ütemezett bankkivétek megnehezítik, ezért később a konkrét feladatok esetén adjuk meg. 


\section{Numerikus elemzés}

A bemutatott modell jóval egyszerủbb a rugalmas nyugdijirendszer modelliénél, de ahhoz, hogy tovább tudjunk lépni, további feltételezésekkel kell élnünk. Elöször is a modellt csak numerikusan fogjuk tudni vizsgálni. Simonovits András és szerzőtársai is numerikusan határozták meg a bemutatott eredményeket, és sok másik tanulmányban is szerepel a bemutatott modell numerikus elemzése (Gupta, 2007, Horneff, Maurer és Stamos, 2008).

A numerikus elemzéshez konkrét értékeket kell megadni paramétereknek. A hasznosságfüggvényben a kockázatelutasitási $\beta$ paraméter értékét 1,25-nek választjuk. Az összegyưijtött tőkét a következőképpen határoztuk meg. A havi bruttó átlagkereset 230000 forint körül van. A járulékmérték tekintetében a szabályozás képlékeny. A 10 százalék munkavállalói nyugdíjárulék könnyen értelmezhetö, a 27 százalékos szociális hozzájárulási adó már nehezebben. A korábbi 24 százalékos munkáltatói TB-járulék nem tűnik irreális közelítésnek. Így összesen havonta 78200 forint járadék keletkezik. 40 évre vetítve 37536 000. Kerekítve és 10000 forintos egységekben számolva 4000 egységnyi tỏke gyűlik össze. Tegyünk fel hozzá valamennyi magánmegtakarítást, így a döntéshozónak 5000 egységnyi tőkéje van. A továbbiakban azt vizsgáljuk, hogy mikorés hogyan érdemes a döntéshozónak ezt a pénzt járadékra váltania. Nem célunk a nyugdírendszer pontos leképezése, hiszen pontosan azt vizsgáljuk, hogy milyennek kellene lennie a nyugdijrendszernek. A döntéshozó szabadon megoszthatja a tőkét a járadék és a bankkivét között, szélső esetben akár a teljes összeget bankkivét formájában fogyaszthatja el. Választhatja azt is, hogy a teljes tőkét járadékként fogyasztja el, ami a magánmegtakaritás járadékra váltását jelenti. Feltételezzük, hogy a magánmegtakaritást ugyanolyan járadékkulcscsal válthatja járadékká, mint a nyugdíj esetében ez megtörténik. Mint később látni fogjuk, a megtakaritás nagyobb részét járadékként fogja elfogyasztani, nem kapunkéletidegen megoldást.

\section{A megtakarítás nagyobb részét \\ járadékként fogja elfogyasztani.}

A modellben csak két típust vizsgálunk: rövid élettartamút és hosszú élettartamút. A numerikus modellezéshez konkrét halálozási adatok szükségesek. A rövid élettartamú típus halálozási adatait a 2009-es évre vonatkozó férfi halálozási valószínűségek fogják reprezentálni, a hosszú élettartamút ugyanezen évre vonatkozó női halálozási valószínüségek. A választást egyszerủen az indokolja, hogy a férfi-női halandósági különbségek jól ismertek (és rendelkezésre állnak a megfelelő adatok a megfelelő bontásban), semmiképpen sem jelenti azt, hogy a nemek közötti diszkriminációt akarnám vizsgálni. Éppen ezért a továbbiakban csak rövid és hosszú várható élettartamú típusról fogok beszélni. A halandósági valószínűségeket a Human Mortality Database oldaláról szereztük be (Human Mortality Database, 2014). A nyugdíikorhatárt 65 évnek tekintettük. A rōvid és hosszú élettartamú típusok esetén a járadékok (nettó) diját az 1. táblázat tartalmazza. A járadékok árában tapasztalható eltérések mintázata jól ismert a szakértők körében.

\begin{tabular}{|c|c|c|c|c|}
\hline $\begin{array}{c}\text { Halasztás } \\
\text { mértéke }\end{array}$ & $\begin{array}{c}\text { Járadék } \\
\text { indulása }\end{array}$ & $\begin{array}{c}\text { Rövid } \\
\text { elettartamú }\end{array}$ & $\begin{array}{c}\text { Hosszú } \\
\text { élettartamú }\end{array}$ & $\begin{array}{c}\text { Hosszú élettartamú } \\
\text { egyenértékes }\end{array}$ \\
\hline 0 & 65 & 14,40 & 18,50 & 18,50 \\
\hline 1 & 66 & 13,40 & 17,50 & 17,50 \\
\hline 2 & 67 & 12,44 & 16,51 & 16,49 \\
\hline 3 & 68 & 11,50 & 15,54 & 15,49 \\
\hline 4 & 69 & 10,60 & 14,58 & 14,50 \\
\hline 5 & 70 & 9,74 & 13,64 & 13,50 \\
\hline 6 & 71 & 8,91 & 12,72 & 12,50 \\
\hline 7 & 72 & 8,11 & 11,81 & 11,51 \\
\hline 8 & 73 & 7,35 & 10,93 & 10,52 \\
\hline 9 & 74 & 6,63 & 10,07 & 9,53 \\
\hline 10 & 75 & 5,95 & 9,23 & 8,55 \\
\hline 11 & 76 & 5,31 & 8,42 & 7,58 \\
\hline 12 & 77 & 4,71 & 7,64 & 6,62 \\
\hline 13 & 78 & 4,15 & 6,89 & 5,68 \\
\hline 14 & 79 & 3,64 & 6,17 & 3,78 \\
\hline 15 & 80 & 3,16 & 5,48 & 3,90 \\
\hline
\end{tabular}

1. táblázat. A rövid és hosszú élettartamú típus esetén a járadékok 1 egységre vonatkozó (nettó) dija 65 éves korban (Forrás: saját számítás)

Antiszelekciós modellekben a nagy kockázatú típus teljes biztositást kap. Ezt mi is feltételezzük. Esetünkben ez annyit jelent, hogy a hosszú élettartamú $h$ típus teljes biztositást fog vásárolni, a teljes megtakarítását járadékra váltja. Kérdés, hogy a rövid élettartamú $r$ típus milyen biztositást vásárolhat, mit kínál(hat) számára a járadékszolgáltató. A modell logikájából következik, hogy teljes biztositást nem kaphat, mert akkor ez a $h$ típus számára is vonzó lenne, és összességében vesztesége keletkezne a járadékszolgáltatónak. Elvi lehetöségként létezhet olyan ár, amely az egész sokaságra nézve kiegyenlíti az eltéréseket, ezt a megoldást keresztfinanszírozásnak hívjuk, és később ejtünk róla szót.

Az $r$ típusnak csak olyan áron adható járadék, ami már nem vonzó a $h$ típusnak. Jelölje $U^{h}\left(t, \ddot{a}_{t}\right)$ azt a maximális hasznosságot, amit a $h$ típus téves halasztott járadék és $\ddot{a}_{t}$ ár esetén el tud érni. Képletben

$$
U^{h}\left(t, \ddot{a}_{t}\right)=\max _{a_{t}^{i}, b_{1}^{i}, b_{2}^{i}, \ldots, b_{3}^{\bar{m}}} u^{i}\left(t, a_{t}^{i}, b_{1}^{i}, b_{2}^{i}, b_{3}^{i} \ldots\right)
$$

feltéve, hogy:

$$
\ddot{a}_{t} a_{t}^{h}+\sum_{\tau=0}^{\omega} p_{\tau}^{i} b_{\tau}^{i}=S
$$

Ekkor a $t$ évvel halasztott életjáradék árát úgy tudja meghatározni a járadékszolgáltató, hogy fennálljon az

$$
U^{h}\left(0, \ddot{a}_{\sigma}\right) \geq U^{h}\left(t, \ddot{a}_{t}\right)
$$


összefüggés. Természetesen az $r$ típus jólétét is szeretnénk maximalizálni, tehát a (4) korlát egyenlöség formájában fog teljesülni minden $t$-re.

A járadékok árának meghatározásánál nehézséget okoz, hogy ha változik a járadék ára $\left(\mathrm{a}_{\mathrm{t}}\right)$, akkor változik az ütemezett bankkivét értéke is. A keresett árakat numerikusan úgy határoztuk meg, hogy kiindultunk a rövid élettartamú típusra vonatkozó járadékok árából, és ezeket az árakat 0,01-gyel csökkentettük mindaddig, amíg fennállt a (4) korlát. Ezeket az árakat tartalmazza az 1. táblázat hosszú élettartamú egyenértékes oszlopa.

Mivel a döntéshozók szeretnék a fogyasztásukat az életpálya mentén kisimítani, másrészről a direkt bankkivét esetén a pénz egy része elvész, ezért ez az egyenértékes kisebb, mint a $h$ típusra vonatkozó halasztott járadék ára. A járadékszolgáltató halasztott járadékot olcsóbban is szolgáltathat, mint a $h$ típus esetén a nettó díj, a $h$ típusnak a számára akkor sem lesz vonzó az ajánlat. Ugyanakkor azt is fontos látni, hogy ezek az értékek még így is rendre nagyobbak, mint az $r$ típus esetén a nettó díj (80 éves korig); bár a típusok halálozási valószínűségeit változtatva máshogy is alakulhatott volna.

Tehát az $r$ típus ezen az árakon felkínált járadékok közül választhat. Számára a hasznosságmaximumot az fogja jelenteni, ha 3 éves halasztott járadékot vásárol, ezt kombinálja a direkt bankkivéttel (lásd 2. táblázat).

\begin{tabular}{|c|c|c|}
\hline Életkor & Járadék & Direkt bankkivét \\
\hline 65 & - & 330,51 \\
\hline 66 & - & 321,62 \\
\hline 67 & - & 313,22 \\
\hline 68 & - & 56,19 \\
\hline 69 & 248,14 & 46,84 \\
\hline 70 & 248,14 & 37,16 \\
\hline 71 & 248,14 & 27,30 \\
\hline 72 & 248,14 & 16,77 \\
\hline 73 & 248,14 & 6,48 \\
\hline 74 & 248,14 & - \\
\hline 75 & 248,14 & - \\
\hline 76 & 248,14 & - \\
\hline 77 & 248,14 & - \\
\hline 78 & 248,14 & - \\
\hline 79 & 248,14 & - \\
\hline $80+$ & 248,14 & - \\
\hline
\end{tabular}

2. táblázat. Az r típus optimális választása (Forrás: saját számítás)
Érdekes megoldás jött ki, ami ellentétes az „igazságérzetünkkel”, de az antiszelekciós modellekben teljesen szokásos: a hosszú (várható) életű típus teljes biztosítást kap, a rövid (várható) életű részlegest, esetünkben ez halasztott életjáradékot jelent. Ha a járadékszolgáltatás megindulását nyugdíjba vonulásként aposztrofáljuk (tudva azt, hogy az analógia sántít), akkor pont ellentétes megoldás jön ki, mint a rugalmas nyugdijrendszer modelljében: a rövidebb várható életű később megy nyugdíjba, mint a hosszabb várható életű.

A megoldással kapcsolatban két fontos megállapítást kell tenni. Egyrészt az $r$ típus nem tudja teljes felhalmozott tőkéjét elfogyasztani, mert a direkt bankkivéteket bizonyos valószínűséggel elveszíti, másrészt a választott járadék a nettó díjánál magasabb. Közgazdaságilag érdekes, hogy a járadékszolgáltató pozitív profitra tehet szert, hiszen a konkurens szolgáltatók sem tudnak alacsonyabb áron járadékot szolgáltatni.

\section{Csökkenő tagú járadék}

Két megoldási lehetőséget érdemes megvizsgálni: az egyik a keresztfinanszírozás, amelyre a következő fejezetben térünk ki. A másik lehetőség az lehetne, ha az $r$ típus választhatna csökkenő tagú járadékot, mivel a későbbi életkorokat kisebb valószínűséggel éli meg. Ez a megoldás nem vonzó a $h$ típus számára. Láthatjuk, hogy az ütemezett bankkivét segítségével részleges módon el lehet érni ezt a csökkenő tagú járadékot.

Általában fontos hangsúlyozni, hogy a járadék (nyugdij) csökken(t)ésének lehetősége technikai oldalról sok problémát megoldana, de a nyugdíirendszert éppen az időskori elszegényedés megakadályozása végett hozták létre, „kényszermegtakarítás”-ként. A rugalmas nyugdíjrendszer modelljében sem szerepel ez a lehetőség (pedig akár szerepelhetne is); a mai gyakorlatot vizsgálva nincs realitása ennek a felvetésnek.

\section{A piacon járadékszolgáltatást vásárolók \\ halandósága jobb az országos átlagnál.}

Az eredmény a tapasztalattal is összeegyeztethető: a hosszabb várható élettartamú ügyfelek (jellemzően jobb módúak) veszik igénybe a járadékszolgáltatásokat, ami így is fogalmazható: a piacon járadékszolgáltatást vásárolók halandósága jobb az országos átlagnál. A rövidebb várható élettartamú (jellemzően kisebb jólétben élők) számára az azonnal vagy közeli jövőben elfogyasztható jövedelem nagyobb súllyal esik latba, külső korlátok nélkül hajlamosabbak felélni a magas életkorra tartalékolt tőkerészt.

\section{Keresztfinanszírozás}

Másik megoldási lehetőség a keresztfinanszírozás. Az $r$ típus nem a járadék jelenértékét szeretné maximalizálni (ebben az esetben nem is létezne járadékpiac), hanem a hasznosságát. 
Tehát hajlandó a jövedelméből bizonyos részt átengedni a $h$ típusnak, cserébe azért, hogy több járadékot (és olcsóbban) vásárolhasson. A keresztfinanszírozás izgalmas kérdés, de a vizsgált modellben csak jelentős számításigény révén elemezhető, és állami beavatkozás (kötelező biztosítás) nélkül a megoldás nem is biztos, hogy stabil. Szempontunkból a keresztfinanszírozással kapcsolatos igazi kérdés az, hogy létrejön-e elegyítő egyensúly, azaz ugyanolyan áron kínálnak-e a járadékszolgáltatók járadékot a két típus számára (kimondatlanul ezt feltételezi Banyár, 2011) Ha nem jön létre elegyítő egyensúly, akkor a Pareto-optimális állapot a fenti mintájú megoldást fogja jelenteni (a $h$ típus teljes biztosítást vásárol, az $r$ pedig halasztott életjáradékot kombinál direkt bankkivétekkel). Nézzük azt az esetet, amikor ugyanazon az áron kínálnak járadékot a két típus számára!

Két kérdést érdemes megvizsgálni. Lehet-e Pareto-optimális állapot a közös járadék, és stabil-e ez az állapot (alkalmas ajánlattal elcsábítható-e az $r$ típus)?

A keresztfinanszírozás vizsgálatához meg kell határozni a típusok arányát az összsokaságban: logikusan adódik a választás, a 65 éves korosztályban a nő-férfi arány legyen a megoszlás a mi esetünkben is. A Human Mortality Database adatai alapján a $h$ típus aránya 57 százalék.

Első fontos megállapításunk, hogy a járadék ára az $r$ típus számára kedvezőtlen, tehát nem fogja a teljes megtakarítását járadékra váltani, hanem bizonyos mennyiséget bankkivétként fog elfogyasztani, csökkentve ezáltal a keresztfinanszírozás mértékét. A konkrét példát tekintve a 65 évesen kínált „uniszex” járadék árának 16,77-nek kell lennie, ekkor a $h$ típus teljes jövedelméből járadékot vesz, az $r$ típus 4 851,88 egységből vesz járadékot. Ezzel mindkét fél jobban jár, mint a korábban leírt szerződés-menüvel.

Ebből az állapotból nehéz elcsábítani az $r$ típust, mert a $h$ típusnak rendre nagyobbak a túlélési lehetőségei, tehát ami vonzó az $r$ típus számára, vonzó a $h$ típus számára is. Nyilván a közös járadék kínálása nagymértékben függ a sokasági arányoktól, de megállapíthatjuk, van esély arra, hogy ez legyen a Pareto-hatékony megoldás, amely egyben stabil is.

\section{Későbbi jövedelemszerzés lehetősége keresztfinanszírozás nélküi}

Vizsgáljuk meg most azt a kérdést, hogy mi történik, ha a típusok elhalasztják a járadékvásárlást (ami számunkra a nyugdíjba vonulás analógiája). Azért érdemes elhalasztaniuk a járadékszolgáltatást, mert jövőbeli munkabér formájában többletjövedelemre tehetnek szert. A nyugdíjrendszer esetén addig nem lehet nyugdíjba vonulni, amíg dolgozik valaki. Azért, hogy a vizsgált modellnek legyen relevanciája a rugalmas nyugdíjrendszer modell számára, mesterségesen kikötjük, hogy a jövőbeli munkabér csak akkor lehetséges, ha még nem indította el (nem vásárolta meg) a járadékszolgáltatást. Értelmes modellben figyelembe kell venni, hogy a munkabér megszerzése áldozatokkal jár. Az életciklus modelljében az éves hasznosságot szorozzák be egy olyan tényezővel, amely miatt ugyanakkora fogyasztás nagyobb haszonnal jár, ha már nyugdíjas az illető, mint ha dolgozik.

Mi más megoldást választunk: feltesszük, hogy a munkaképes állapot fenntartása áldozattal jár, és ez az áldozat pénzben mérhető (ami nem idegen a biztosítási modellektől); ráadásul az idő előrehaladtával egyre nagyobb az áldozat (költség). A munkabért (évi) 200 egységnek tekintem (havi szinten ez 200×10 000/12=166 667 forintnak felel meg, ami egész közel van a jelenlegi nettó átlagbérhez). A munkaképes állapot fenntartásának költsége a t. évben: $\widetilde{q}_{t}^{i} C$ ahol, $\widetilde{q}_{t}^{i}$ a típusfüggő koréves halálozási valószínűség. A $C$ paraméter értékét úgy állítom be, hogy a $h$ típus esetén 80 éves korban már ne tegyen szert (nettó) munkabérre. Ezzel a megoldással azt is el tudom érni, hogy a hosszabb várható élettartamú típus nagyobb többletjövedelemre tesz szert a későbbi munkavégzésből, ami egybevág a gyakorlattal. Ekkor az $r$ és a $h$ típus a 3. táblázat szerinti nettó jövedelmeket tudja elérni ${ }^{3}$.

\begin{tabular}{|c|c|c|}
\hline Életkor & $\boldsymbol{r}$ típus & $\boldsymbol{h}$ típus \\
\hline 65 & 97,0 & 159,1 \\
\hline 66 & 92,2 & 155,6 \\
\hline 67 & 84,0 & 148,5 \\
\hline 68 & 79,4 & 147,2 \\
\hline 69 & 71,2 & 138,1 \\
\hline 70 & 64,2 & 132,0 \\
\hline 71 & 49,9 & 129,4 \\
\hline 72 & 44,1 & 122,7 \\
\hline 73 & 34,8 & 114,1 \\
\hline 74 & 8,4 & 97,3 \\
\hline 75 & 0 & 89,1 \\
\hline 76 & 0 & 84,6 \\
\hline 77 & 0 & 58,4 \\
\hline 78 & 0 & 41,7 \\
\hline 79 & 0 & 28,3 \\
\hline $80+$ & 0 & 0 \\
\hline
\end{tabular}

3. táblázat. 65 éves kor után elérhető többletjövedelmek az rés h típus számára (Forrás: saját számítás)

Először nézzük azt az esetet, amikor a $h$ típus 1 évvel (de többel nem) elhalaszthatja a járadékvásárlást. Ekkor 1 év múlva, ha életben van, a tőkéje 159,1 egységgel nő, ami 65 évesen várhatóan 157,1 egységet jelent, tehát összességében 5 157,1 egységet oszthat el, de az első év fogyasztását csak bankkivét formájában finanszírozhatja. A modellünk feltételeivel élve érdemes ezt megtennie, így évente 279,0 egységet tud elfogyasztani, hasznossága is nő. Nézzük az $r$ típus választását! Ha ő nem halasztja el a járadékszolgáltatás indítását, akkor csökkentett áron juthat járadékhoz, hiszen ha a $h$ típus is azonnal induló járadékot akar vásárolni, le kell mondania a plusz jövedelméről. Az $r$ típus inkább lemond a későbbi többletjövedelméről és, azonnal járadékot vásárol - nem a teljes felgyülemlett pénzből, egy részét megtartja bankivétnek. 
Ha a $h$ típus szabadon dönthet a járadékvásárlás megindításának idejéről, akkor 74 éves korában indítja a járadékot. Ezzel lényegesen jobb helyzetbe kerül, mint ha rögtön 65 évesen nyugdíjba menne. Ezáltal változnak a korábban bemutatott egyenértékesek is (4. táblázat).

Látható, hogy az egyenértékes 74 éves korban egyezik meg a hosszú élettartamú típus nettó díjával, ami triviális is, hiszen a $h$ típus ekkor indítja a járadékát. A korai életkorokban ez az egyenértékes jóval alatta van a $h$ típusra vonatkozó járadékok árának, hiszen korábbi járadékindítás esetén jelentős többletjövedelemről kellene lemondania a $h$ típusnak; de még így is felette van az $r$ típus értékeinek.

\begin{tabular}{|c|c|c|c|c|}
\hline $\begin{array}{c}\text { Halasztás } \\
\text { mértéke }\end{array}$ & $\begin{array}{c}\text { Járadék } \\
\text { indulása }\end{array}$ & $\begin{array}{c}\text { Rövid } \\
\text { élettartamú }\end{array}$ & $\begin{array}{c}\text { Hosszú } \\
\text { élettartamú }\end{array}$ & $\begin{array}{c}\text { Hosszú élettartamú } \\
\text { egyenértékes }\end{array}$ \\
\hline 0 & 65 & 14,40 & 18,50 & 15,76 \\
\hline 1 & 66 & 13,40 & 17,50 & 15,26 \\
\hline 2 & 67 & 12,44 & 16,51 & 14,73 \\
\hline 3 & 68 & 11,50 & 15,54 & 14,17 \\
\hline 4 & 69 & 10,60 & 14,58 & 13,58 \\
\hline 5 & 70 & 9,74 & 13,64 & 12,95 \\
\hline 6 & 71 & 8,91 & 12,72 & 12,27 \\
\hline 7 & 72 & 8,11 & 11,81 & 11,58 \\
\hline 8 & 73 & 7,35 & 10,93 & 10,84 \\
\hline 9 & 74 & 6,63 & 10,07 & 10,07 \\
\hline 10 & 75 & 5,95 & 9,23 & 9,08 \\
\hline 11 & 76 & 5,31 & 8,42 & 8,10 \\
\hline 12 & 77 & 4,71 & 7,64 & 6,13 \\
\hline 13 & 78 & 4,15 & 6,89 & 6,17 \\
\hline 14 & 79 & 3,64 & 6,17 & 5,24 \\
\hline 15 & 80 & 3,16 & 5,48 & 4,33 \\
\hline
\end{tabular}

4. táblázat. (Forrás: saját számítás)

A 4. táblázat megmutatja, hogy mennyi lenne a rövid és hosszú élettartamú típus esetén a járadékok 1 egységre vonatkozó (nettó) díja 65 éves korban.

A kérdés az, hogy mikor indítja az $r$ típus a járadékot. Akkor tudja hasznosságát maximalizálni, ha rögtön 65 éves korban elindítja a járadékot.

Látjuk, hogy most ugyanaz a kép rajzolódik ki, mint a rugalmas nyugdíjrendszer modelljében. A hosszabb várható életű típus később indítja a járadékot, a rövidebb várható életű pedig korábban. Fontos azonban azt is hangsúlyozni, hogy a rövidebb várható életü is szívesen halasztaná a járadékindítást, hogy további jövedelemre tegyen szert a későbbi életkorokban, de a járadékok árai ebben ellenérdekeltté teszik. Tehát az $r$ típus jobban jár ebben a felállásban, mintha nem lehetne a későbbi életkorokban is jövedelmet szerezni, de a saját lehetőségeihez képest még mindig rosszabbul jár. Ha nem létezne a $h$ típus, és az $r$ típus teljes biztosítást vásárolhatna, akkor ő is csak 69 évesen menne nyugdíba, ami kevesebb, mint a $h$ típus esetén a 74 év, de több, mint az optimális választásként adódó 65 . Fontos tehát azt is látni, hogy a rugalmas nyugdíjrendszer modellje ellenérdekeltté teszi a rövid élettartamú típust a minél későbbi járadékindításra (nyugdíjba vonulásra).

\section{Későbbi jövedelemszerzés lehetősége keresztfinanszírozással}

Utolsó pontként vizsgáljuk meg, hogy keresztfinanszírozással javítható-e mindkét típus helyzete. A keresztfinanszírozás tálcán kínálja magát, hiszen az $r$ típus még mindig csak drágábban tud járadékhoz jutni, mint amennyi a rá vonatkozó nettó díj. Keresztfinanszírozás nélkül 10,07-es áron kínálja a járadékszolgáltató a 9 évvel halasztott életjáradékot, és 15,76-os áron az azonnal induló járadékot. Keresztfinanszírozott esetben ezek az árak rendre 9,47 és 15,23 , így a járadékszolgáltató annyit nyer az $r$ típuson, amennyit veszít a $h$ típuson, természetesen úgy, hogy közben az ösztönzési rendszer sem sérül. Mivel mind a két típus esetén csökkentek az árak, ez mindkét típus számára kedvező változás.

Keresztfinanszírozás ennél tágabb keretben is elképzelhető, akár úgy is, hogy a Pareto-optimális állapotban megváltozik a járadékindítás időzítése. A direkt bankkivétek sokféle lehetősége most is nagyon bonyolulttá teszi a globális optimum megkeresését 


\section{Összefoglalás}

A rugalmas nyugdíjrendszer modelljébe szerettük volna beépíteni a bizonytalan várható élettartam modellezését. Az eredeti Eső-Simonovits-Tóth (2011) modell beláthatatlanul bonyolulttá vált volna, ezért egy másik kiindulópontból vizsgáltuk a kérdést, piaci modellt feltételeztünk, és a dolgozók racionális választását vizsgáltuk.

A bemutatott modellben reprodukálni tudtuk a rugalmas nyugdíjrendszer modelljének főbb állításait. A hosszabb várható élettartamú típus későbbre igényli a járadékszolgáltatást, a rövidebb várható élettartamú típus pedig korábbra. Bemutattuk azt is, hogy a keresztfinanszírozás Pareto-hatékony elmozdulást okozhat. Az eredmények azt is jelentik, hogy az ütemezett bankkivétek megjelenése nem okoz drasztikus változást a modellben, ezáltal a rendszer viszonylag stabilnak tekinthető.

Rámutattunk a modell alkalmazhatóságának korlátaira. A hosszabb várható élettartamú személy későbbi járadékindításában döntő szerepe volt a később megszerezhető jövedelemnek. Ha a későbbi életkorban megszerezhető többletjövedelem (munkabér) mértéke kicsi, vagy a jövedelem megszerzésének nagy a költsége, akkor paradox megoldás állhat fenn: a hosszabb várható élettartamú típus megy korábban nyugdíjba (vagy egy keresztfinanszírozott közös járadékot kínálnak).

Rámutattunk arra is, hogy az ösztönzési rendszer a rövid várható élettartamú típust korábbi járadékvásárlásra ösztönzi, mint a teljes információjú esetben, tehát a rugalmas nyugdíjrendszer jóléti veszteséget okoz a rövidebb várható élettartamú típusnak, ami keresztfinanszírozással valamennyire csökkenthető, de nem szüntethető meg.

Végül felhívtuk a figyelmet arra is, hogy a kapott eredmények fontos előfeltétele a csökkenő tagú életjáradékok meg nem engedése. Ha megengedjük a csökkenő tagú életjáradékot, alapvetően megváltozhat a rendszer.

\section{HIVATKOZÁSOK}

'Szeretném köszönetemet kifejezni Simonovits Andrásnak értékes gondolataiért. A maradék hibákért engem terhel a felelösség.

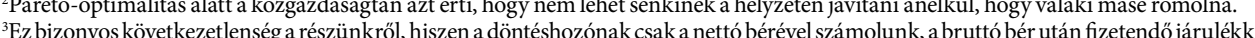
(szolidaritási adóval) már nem. Igazából a modell szempontiából csak az a lényeg hogy mekkora bevételre tesz szert a döntéshozó

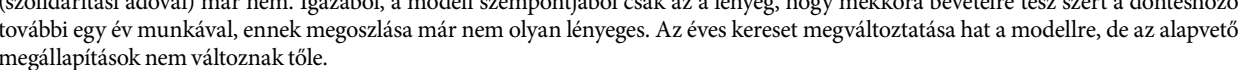

\section{IRODALOMJEGYZÉK}

The

Banyár.., Mészáros J. (2004): Egylehetséges nyugdijeformés indokai, Társadalom és Gazdaság, 2. sz. 113-141. old. http://dx.doi.org/10.1556/ tarsgazd.26.2004.2.2

M., Peled, D. (1985): Uncertain Lifetimes and the Welfare Enhancing Properties of Annuity Markets snd Social Dol. 26., 303-326. old. http://dx doiorg/10.1016//0047-2727(85)90012-x 61., 3-32. old. http://dx.doi.org/10.1556/aoecon.61.2011.1.2

Esô P., Simonovits A. (2003): Optimális járadékfüggvény tervezése rugalmas nyugdíjrendszerre, Közgazdasági Szemle, 50. évf., február, 99-111. old.

(1973): A Life Cycle Model of Life Insurance Purchases, International Economic Review, vol. 14., issue 1, 132-152. old. http://

政

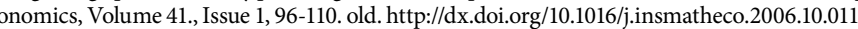

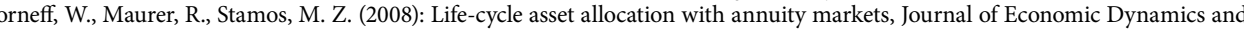
Control, Volume 32, Issue 11., 3590-3612. old. http://dx.doi.org/10.1016/j.jedc.2008.01.007

.

1981), 372-391. old http.//dx doi rog /10.1086/260970 政 Mitchell, O. S.; Poterba, J. M.; Warshawsky, M. J.; Brown, J. R. (1999): New Evidence on the Money's Worth of Individual Annuities, The

ció, Közgazdasági Szemle,

Simonovits A. (2012): Még egyszer az eszmei nyugdijiszámla elvi hibáááról, Szzigma, 43. évf, 3-4. szám, 145-160. old. 